\title{
ROLE OF INCLUSIONS FOR FORMATION OF ACICULAR FERIT IN LOW CARBONSTEEL WELD DEPOSITS
}

\section{ULOGA UKLJUČAKA KOD STVARANJA ACIKULARNOG FERITA NA DEPONOVANOM METALU ŠAVA NISKOUGLJENIČNOG ČELIKA}

\author{
Originalni naučni rad / Original scientific paper \\ UDK / UDC: Weld World (2014) 58:491-497; \\ Dol 10.1007/s40194-014-0132-0 \\ Rad primljen / Paper received: \\ Mart 2015.
}

Prevod izvornog rada na srpski jezik: Milica Antić,dipl.ing

Key words: Low carbon steel weld deposits, Inclusions, Acicular ferit, Crystallographic analysis

\begin{abstract}
Acicular ferit was investigated from the viewpoint of orientation relationships among acicular ferit, prior austenite, and inclusions. The Baker-Nutting orientation relationship was observed between acicular ferit and a $\mathrm{TiO}$ layer forming at inclusion surfaces. Meanwhile, the Kurdjumov-Sachs orientation relationship was observed between acicular ferit and prior austenite. The results indicate that acicular ferit is considered to nucleate due to a low misfit with $\mathrm{TiO}$ layers; however, there is still doubt. In case the $\mathrm{TiO}$ layer form at molten steel, its orientation would be random with austenite. Thus, acicular ferit nucleating with the Baker-Nutting orientation relationship should have no orientation relationship with austenite. In order to address the issue, the inclusion formation process was investigated by using the liquid-tin quenching technique and the thermodynamic calculation. The results reveal that $\mathrm{TiO}$ form not at the high temperature such as molten steel temperature but at below the solid phase temperature such as austenite or ferit temperature. As the result of orientation analysis between prior austenite and $\mathrm{TiO}, \mathrm{TiO}$ is not considered to form in austenite. It can be assumed that $\mathrm{TiO}$ layers form in order to match interface with acicular ferit. Additionally, the $\mathrm{Mn}$ depleted zone were also not observed. Therefore, acicular ferit is considered to nucleate not due to the low misfit or the $\mathrm{Mn}$ depleted zone but due to another mechanism.
\end{abstract}

\author{
Adresa autora / Author's address: \\ ${ }^{1}$ Graduate School of Engineering Osaka University \\ 2 Joining and Welding Research Institute Osaka University \\ Corresponding author. Tel.:+81 668794377 \\ E-mail address: takada-a@jwri.osaka-u.ac.jp
}

Ključne reči: depoziti metala šava od niskougljeničnog čelika, ukjlučci, acikularni ferit, kristalografska analiza

\section{Apstrakt}

Acikularni ferit je istraživan s gledišta orijentacije odnosa acikularnog ferita, primarnog austenita i uključaka. Zapažena je Baker-Nutting orijentacija odnosa igličastog ferita i sloja TiO koji se formira na površini uključaka. U međuvremenu, zapažena je Kurdjumov-Sachs orijentacija odnosa igličastog ferita i primarnog austenita. Rezultati pokazuju da se acikularni ferit smatra jezgrom zbog male nepodobnosti sa slojevima $\mathrm{TiO}$; međutim, još uvek postoji sumnja. U slučaju kada se sloj TiO obrazuje iz rastopljenog čelika, njegova orijentacija bi bila slučajna sa austenitom. Dakle, acikularni ferit nastao sa Baker-Nutting orijentacijom ne bi trebalo da ima orijentacijski odnos s austenitom. U cilju rešavanja problema, proces formiranja uključaka, ispitan je pomoću tehnike kaljenja tečnim kalajem i termodinamičkim proračunom. Rezultati su pokazali da se ne stvara TiO pri visokoj temperaturi kao što je temperatura rastopa čelika ali se stvara ispod temperature čvrstih faza, kao što su temperature austenita i ferita. Kao rezultat analize orijentacije primarnog austenita i $\mathrm{TiO}$, smatra se da se $\mathrm{TiO}$ ne formira u austenitu. Može se pretpostaviti da stvoreni slojevi TiO čine pogodnu međupovršinu sa acikularnim feritom. Osim toga, nije zapažena zona osiromašena na $\mathrm{Mn}$. Stoga se smatra da se acikularni ferit ne stvara usled male nepodudarnosti ili osiromašenih zona na $M n$, već drugim mehanizmom. 


\section{Introduction}

In low carbon steel weld deposits, an acicular ferrite microstructure is considered as the optimum structure in terms of strength and toughness ${ }^{1-3)}$. The microstructure consist of interlocked fine grains and high angle grain boundaries ${ }^{4-6)}$. In general low carbon steel weld deposits, the austenite to ferrite transformation occurs from austenite grain boundaries $^{1,2,7)}$. The ferrites nucleating at austenite grain boundaries such as grain boundary ferrite or ferrite side plate are tendency to form a coarse microstructure. However, when transformation at austenite grain boundaries are suppressed and inclusion compositions are controlled, ferrite nucleates at austenite/inclusion interfaces ${ }^{8,9}$. The ferrite nucleating at an inclusion interface is referred to as acicular ferrite due to the morphology. It grows radially from each inclusion and impinge another acicular ferrite grains $\mathrm{s}^{4,6)}$ The formation mechanism of acicular ferrite result in an interlocked fine microstructure with high angle grain boundaries ${ }^{5,10)}$

Since the late 1970s when the acicular ferrite microstructure was identified, many researches relating to acicular ferrite nucleation mechanisms were carried out ${ }^{1-18)}$. The role of inclusion has been discussed, and several nucleation mechanisms have been proposed ${ }^{11-18)}$; however, the nucleation mechanism of acicular ferrite has not been established. As one of the possible nucleation mechanisms, it was proposed that acicular ferrite nucleates due to a low misfit with inclusion phases $^{14,16)} \mathrm{TiO}, \mathrm{TiN}$, and spinel structures are known to be as the phases having a low misfit with ferrite $^{13-15)}$. The minimum misfit is represented when the Baker-Nutting orientation relationship is observed between ferrite and the phases ${ }^{16,19)}$.

In practice, $\mathrm{TiO}$ layers have been observed at inclusion surfaces by microscopic observation; moreover, the Baker-Nutting orientation relationship has been identified between the $\mathrm{TiO}$ layers and the adjacent ferrite ${ }^{16)}$.

Meanwhile, the KurdjumovSachs orientation relationship exists between acicular ferrite and prior austenite ${ }^{3,4>7>10)}$. Acicular ferrite has been identified as intragranularly nucleated bainite ${ }^{7)}$; thus, the KurdjumovSachs orientation relationship is observed in acicular ferrite as well as bainite or martensite. It is indicated that the two orientation relationships are involved in acicular ferrite nucleation. One is the Baker-Nutting orientation relationship between acicular ferrite and the inclusion, and the other is the Kurdjumov-Sachs orientation relationship between acicular ferrite and prior austenite.

\section{Uvod}

Kod metala šava niskougljeničnih čelika, mikrostruktura sa acikularnim feritom se smatra optimalnom sa aspekta čvrstoće $i$ žilavosti ${ }^{1-3)}$. Mikrostruktura se sastoji od međusobno zakačenih finih zrna i granica zrna pod velikim uglom ${ }^{4-6)}$. U opštem slučaju, kod depozita niskougljeničnih čelika, transformacija austenita u ferit javlja se po granicama austenitnih zrna ${ }^{1,2,7)}$. Ferit koji nastaje na granicama austenitnog zrna kao i zrna po granicama ferita ili strani feritnih ploča imaju tendenciju da formiraju grubu mikrostrukturu. Međutim, kada se transformacija na granici zrna austenita potisne a sastav uključaka kontroliše, ferit nastaje na međupovršinama austenit / uključak ${ }^{8,9) .}$ Ferit koji nastaje na međupovršini uključka naziva se acikularni ferit zbog morfologije. On raste radijalno iz svakog uključka i utiče na druga zrna acikularnog ferita ${ }^{4,6)}$ Mehanizam formiranja acikularnog ferita, rezultuje u međusobno zaključanoj finoj mikrostrukturi s velikim uglom granica zrna ${ }^{5,10}$.

Kasnih 1970-ih, kada je identifikovana mikrostruktura acikularnog ferita, sprovedena su mnoga istraživanja koja se odnose na mehanizme nukleacije acikularnog ferita ${ }^{1-18)}$. Uloga uključaka se raspravlja, a nekoliko mehanizmama nukleacije je predloženo ${ }^{11-18) ; ~ m e đ u t i m, ~ m e h a n i z a m ~ n u k l e a c i j e ~}$ acikularnog ferita nije utvrđen.

Kao jedan od mogućih mehanizama nukleacije, smatrano je da acikularni ferit nastaje zbog niske nepodobnosti sa fazama uključaka ${ }^{14,16)}$. Za TiO, TiN i spinel strukture se zna da kao faze imaju nisku nepodobnost sa feritom ${ }^{13-15)}$. Minimalna nepodobnost uočena je kod Baker-Nutting orijentacije odnosa ferita i faza ${ }^{16,19)}$.

$\mathrm{U}$ praksi, TiO slojevi su primećeni na površini uključaka pri mikroskopskom posmatranju; štaviše, Baker-Nutting orijentacija odnosa utvrđena je između slojeva TiOi susednog ferita ${ }^{16)}$.

U međuvremenu, Kurdjumov-Sachs orijentacija odnosa postoji između acikularnog ferita i primarnog austenita 3, 4, 7, 10). Acikularni ferit je identifikovan kao unutargranularni nastao beinit ${ }^{7}$; dakle, Kurdjumov-Sachs orijentacija odnosa se javlja kod acikularnog ferita, kao i beinita ili martenzita. Pokazano je da su dve orijentacije veza uključenih u nukleaciju acikularnog ferita. Jedna od njih je Baker-Nutting orijentacija odnosa acikularnog ferita i uključaka, a drugi je KurdjumovSachs orijentacija odnosa acikularnog ferita i primarnog austenita. 
In this study, crystallographic orientation relationships were investigated among acicular ferrite, inclusions, and prior austenite. Additionally, the formation process of inclusions, which have a dominant influence on acicular ferrite formation, were investigated by using the liquid-tin quenching technique $^{20)}$ and the thermodynamic calculation. In consideration of the results, the acicular ferrite nucleation mechanisms were estimated.

\section{Experimental}

Specimens were low carbon steel welds fabricated by submerged arc welding process. TiB containing wires were used in order to stimulate acicular ferrite formation. Chemical compositions of the weld deposits are shown in Table 1.
U ovoj studiji, istraživani su odnosi kristalografske orijentacije acikularnog ferita, uključaka i primarnog austenita. Osim toga, procesi stvaranja uključaka, koji imaju dominantan uticaj na stvaranje acikularnog ferita, ispitani su tehnikom kaljenja u rastopljenom kalaju ${ }^{20)}$ i termodinamičkim proračunom. U razmatranju rezultata, mehanizmi nukleacije acikularnog feritanisu određeni.

\section{Eksperiment}

Epruvete su od zavarenih spojeva niskougljeničnog čelika zavarenih EPP postupkom. Radi stimulisanja nastajanja acikularnog ferita, korišćena je žica koja sadrži TiB. Hemijski sastav metala šava prikazan je u tabeli 1.

\begin{tabular}{cccccccccc}
\hline $\mathrm{C}$ & $\mathrm{Si}$ & $\mathrm{Mn}$ & $\mathrm{P}$ & $\mathrm{S}$ & $\mathrm{Ti}$ & $\mathrm{Al}$ & $\mathrm{B}$ & $\mathrm{O}$ & $\mathrm{N}$ \\
\hline 0.062 & 0.26 & 1.47 & 0.012 & 0.004 & 0.014 & 0.005 & 0.0028 & 0.018 & 0.0044 \\
\hline
\end{tabular}

Table 1 Chemical compositions of weld metals

Tabela 1 Hemijski sastav metala šava

Microstructures were observed with optical microscopy (OM). Samples were mirror polished and etched by $2 \%$ nital. Inclusions were observed with transmission electron microscopy (TEM). Thin foils for TEM observations were prepared by the focused ion beam (FIB) milling.

Elemental compositions of inclusions were analyzed with energy dispersive X-ray spectrometry (EDS). Inclusion phases were identified by selected area diffraction patterns (SADPs). Inclusion and ferrite orientation relationships were investigated by SADP. The orientation relationship between acicular ferrite and prior austenite is investigated using electron backscatter diffraction (EBSD) technique. Samples for EBSD were prepared using across section polisher. The orientation data were measured with a $100 \mathrm{~nm}$ step size. As reliable data of retained austenite orientations was not obtained, the prior austenite orientations were determined with the prior austenite reconstruction method ${ }^{21)}$.

The schematic illustration of the liquid-tin quenching technique is shown in Fig. 1. A coated electrode was set in a welding groove. Tungsten inert gas welding was practiced on the coated electrode. The welding current is $150 \mathrm{~A}$ and the welding speed is $2 \mathrm{~mm} / \mathrm{s}$. Liquid-tin melted at $300^{\circ} \mathrm{C}$ were poured onto weld deposits in the welding process, and quenched weld deposits were prepared. The thermal distribution of deposits before quenching was estimated by using heat conduction analysis.
Mikrostrukture su uočene optičkim mikroskopom (OM). Uzorci su polirani do ogledalastog sjaja i nagriženi $2 \%$ nitalom. Uključci su posmatrani transmisionim elektronskim mikroskopom (TEM). Tanke folije za TEM posmtaranja, pripremljene su glodanjem fokusiranim snopom jona (FIB). Elementarni sastavi uključaka analizirani su energijom disperzivne rendgenske spektrometrije (EDS). Faze uključaka identifikovane su preko odabranih područja difrakcijskih uzoraka (SADP). Orijentacija odnosa uključka i ferita ispitivana je pomoću SADP.

Odnos između orijentacije acikularnog ferita i primarnog austenita istražen je pomoću tehnike difrakcije povratno raspršenih elektrona (EBSD). Uzorci za EBSD su pripremljeni poliranjem poprečnog preseka. Orijentacioni podaci su mereni sa veličinom koraka $100 \mathrm{~nm}$. Kao pouzdani podatak, orijentacija zaostalog austenita nije dobijena, a orijentacije primarnog austenita su određene metodom rekonstrukcije primarnog austenita ${ }^{21) .}$

Šematski prikaz tehnike kaljenja rastopljenim kalajem dat je na slici 1 . Obložena elektroda je postavljena u žljeb za zavarivanje. TIG zavarivanje je isprobano na obloženoj elektrodi. Jačina struje zavarivanja je $150 \mathrm{~A}$ i brzina zavarivanja je $2 \mathrm{~mm} / \mathrm{s}$. Tečni kalaj istopljen na $300^{\circ} \mathrm{C}$ se izliva preko deponovanog zavara i kaljeni metal šava je pripremljen. Distribucija toplote depozita pre kaljenja procenjena je pomoću analize provođenja toplote. 
In order to estimate the inclusion formation behavior, the thermodynamic calculation were carried out by using FactSage software. The equilibrium conditions were calculated from $300^{\circ} \mathrm{C}$ to $2200^{\circ} \mathrm{C}$. As for the calculation conditions, all weld deposit compositions excluded phosphorus and nitrogen were used, and FToxide and FSstel were used as the databases.
Kako bi se procenilo ponašanje formiranja uključaka, termodinamički proračun je sproveden pomoću FactSage softvera. Uslovi ravnoteže su izračunati od $300^{\circ} \mathrm{C}$ do $2200^{\circ} \mathrm{C}$. Za uslove proračuna, korišćeni su sastavi metala šava, izuzev fosfora i azota, a FToksid i FSstel korišćeni su kao baza podataka.

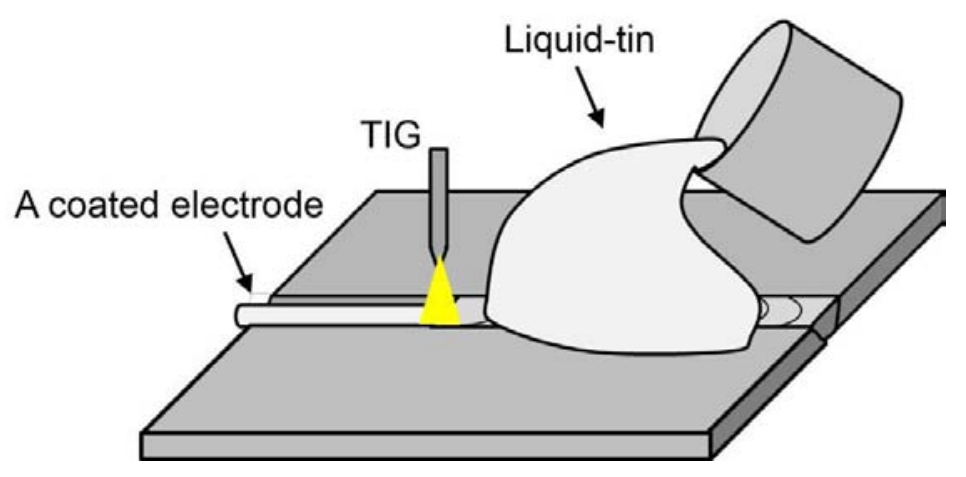

Fig. 1. Schematic illustration of liquid-tin quenching SI. 1. Šematska ilustracija kaljenja tečnim kalajem

\section{Results}

Amicrostructure of weld deposits is shown in Fig. 2. The fine acicular ferrite microstructure is observed. Figure 3 shows a SEM micrograph of inclusion. The inclusion is a spherical shape and several ferrite grains elongating from the inclusion are observed.

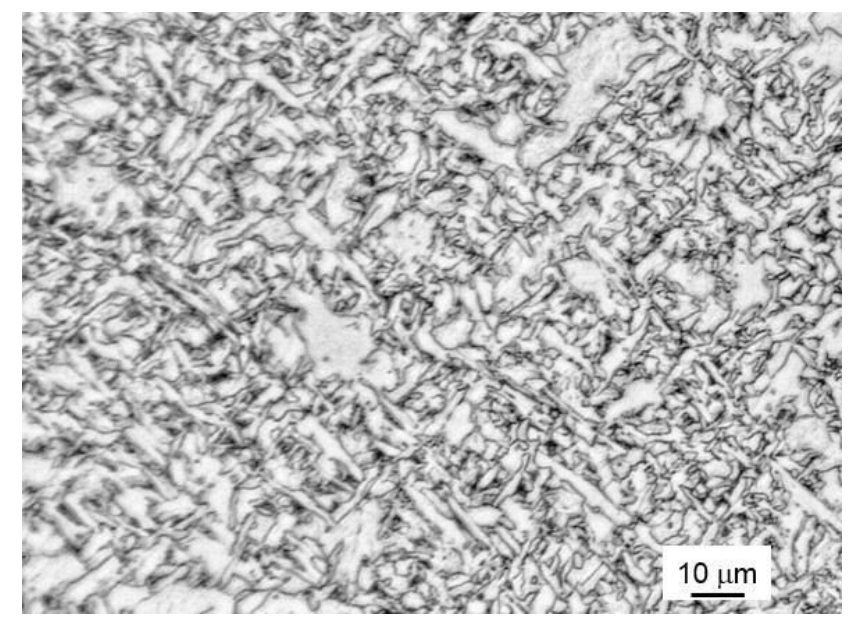

Fig. 2 The microstructure of welds SI.2 Mikrostruktura šava

Figure 4 shows the elemental distributions of inclusion. As shown in Fig. 4, the inclusion consists of the multiple phases. The Ti-rich layer is observed at the surface of inclusion; additionally, it form a planar interface with ferrite. From the results of SADP, the phases in the inclusion identified as the amorphous phase, the spinel structure, and a-MnS.

\section{Rezultati}

Mikrostruktura deponovanog metala šava data je na sl.2. Zapaža se mikrostruktura finog acikularnog ferita. Na sl.3 prikazan je SEM mikrograf uključka. Zapaža se uključak sfernog oblika i nekoliko izduženih feritnih zrna.

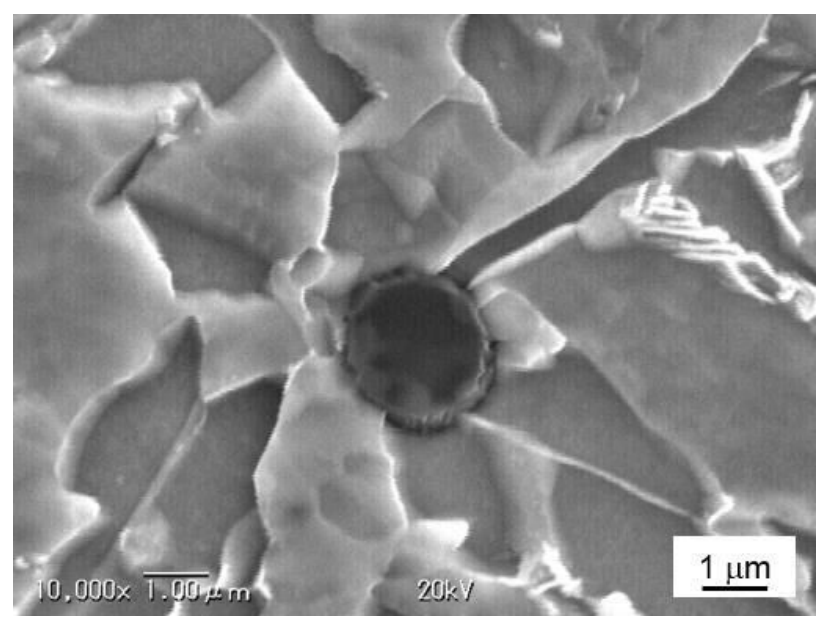

Fig. 3 The SEM micrograph of inclusion SI.3 SEM mikrograf uključka

Na sl.4 prikazana je raspodela elemenata uključka. Kao što je prikazano na sl.4 uključak se sastoji od vise faza. Sloj bogat Ti zapaža se na površini uključka; dodatno, stvara planarnu međupovršinu sa feritom. Iz rezultata SADP, faze u uključku identifikovane su kao amorfne, strukture spinela, i a-MnS. 
Figure 5(a) shows the TEM micrograph of the interface between the inclusion and ferrite. The SADP of Fig.5(b) was obtained by the circle in Fig.5(a). The SADP indicate that the Ti layer is TiO, additionally, the Baker-Nutting orientation relationship is identified between the inclusion and adjacent ferrite.

Figure 6(a) shows an inverse pole figure (IPF) map of ferrite phase and (b) shows the <001> pole figure. The black circle in Fig.6(a) indicate the inclusion. The several grains elongating from the inclusion are observed. The calculated prior austenite orientation is plotted at blue squares in Fig.6(b). The 24 Kurdjumov-Sachs variants are plotted as yellow circles. The ferrite orientation indicated by the arrow in Fig.6(a), which represents the nucleation points, is plotted at the red points in Fig.6(b). As shown in the figure, the deviation between the ferrite orientation and the nearest Kurdjumov-Sachs variants is only a few degree; therefore, it is identified that acicular ferrite nucleates with almost the Kurdjumov-Sachs orientation relationship. Figure 7 shows the cross section image of weld deposits quenched by liquidtin. Steel and tin are mixed in the place which existed as molten steel before quenching. The calculated thermal distribution is shown in Fig. 8. The lines in the figure indicated $800^{\circ} \mathrm{C}$ and $600^{\circ} \mathrm{C}$. From the calculation results, it is estimated that the temperature of area 3 in Fig. 8 was below the ferrite transformation temperature. Figure 9(a) (f) show the TEM bright field images and $\mathrm{Ti}$ distributions of the inclusions extracted from the areas indicated by numbers in Fig. 7 .
Na sl.5(a) prikazan je TEM micrograf međupovršina uključka i ferita. SADP sa sl.5(b) dobijen je iz kruga sa sl.5(a). SADP indikuje da je Ti sloj TiO, dodatno, Baker-Nutting orijentacije odnosa uključka i susednog ferita.

Na slici 6(a) prikazana je inverzna slika pola (IPF) mapeferitne faze i (b) koja pokazuje <001>sliku pola. Crni krug sa sl.6(a) indikuje uključak. Zapaženo je nekoliko izduženih zrna iz uključka. Proračunata orijentacija primarnog austenita prikazana je plavim kvadratima na sl.6(b). Kurdjumov-Sachs 24varijante prikazane su kao žuti krugovi.Orijentacija ferita naglašena je strelicom na sl. 6(a), koja reprezentuje tačke nukleacije, prikazane su kao crvene tačke na sl. 6(b). Kao što je prikazano na slici, odstupanje između orijentacije ferita i najbližih Kurdjumov-Sachs varijanti je samo nekoliko stepeni; stoga, utvrđeno je da acikularni ferit nastaje sa skoro Kurdjumov-Sachs orijentacijom odnosa.

$\mathrm{Na}$ sl.7. prikazan je poprečni presek deponovanog metala šava kaljenog tečnim kalajem. Čelik i kalaj se mešaju u mestu koje je postojalo kao rastopljeni čelik pre kaljenja. Izračunata termička raspodela prikazana je na sl.8. Linije na slici označavaju $800^{\circ} \mathrm{C}$ i $600^{\circ} \mathrm{C}$. Iz rezultata proračuna, procenjeno je da je temperatura oblasti 3 sa sl.8 bila ispod temperature transformacije ferita. $\mathrm{Na}$ slikama 9(a) (f) prikazana su TEM polja svetlih slika i raspodela $\mathrm{Ti}$ uključaka ekstaktovanih iz površina označenih brojevima sa sl.7.
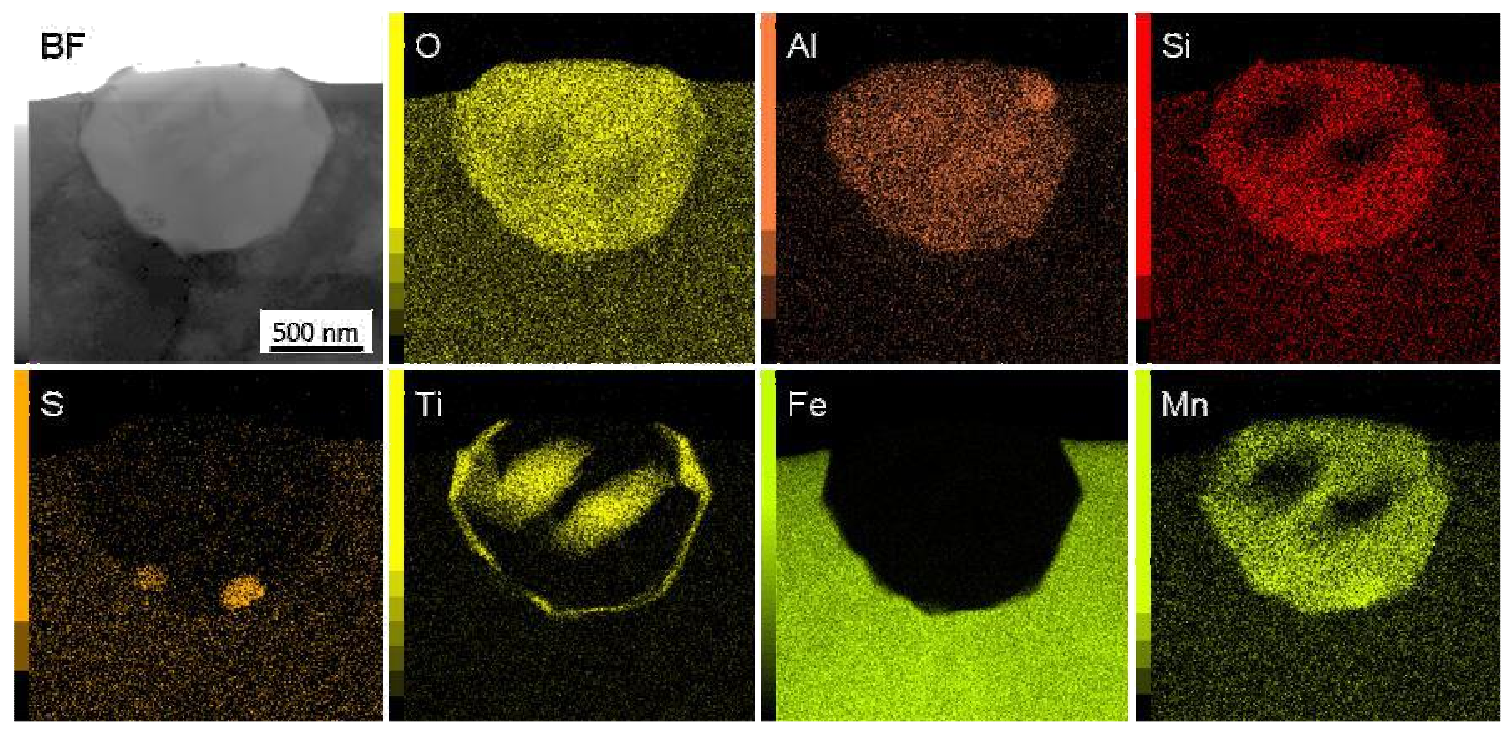

Fig. 4 EDS mappings of inclusion

SI. 4.EDS kartografija uključka 

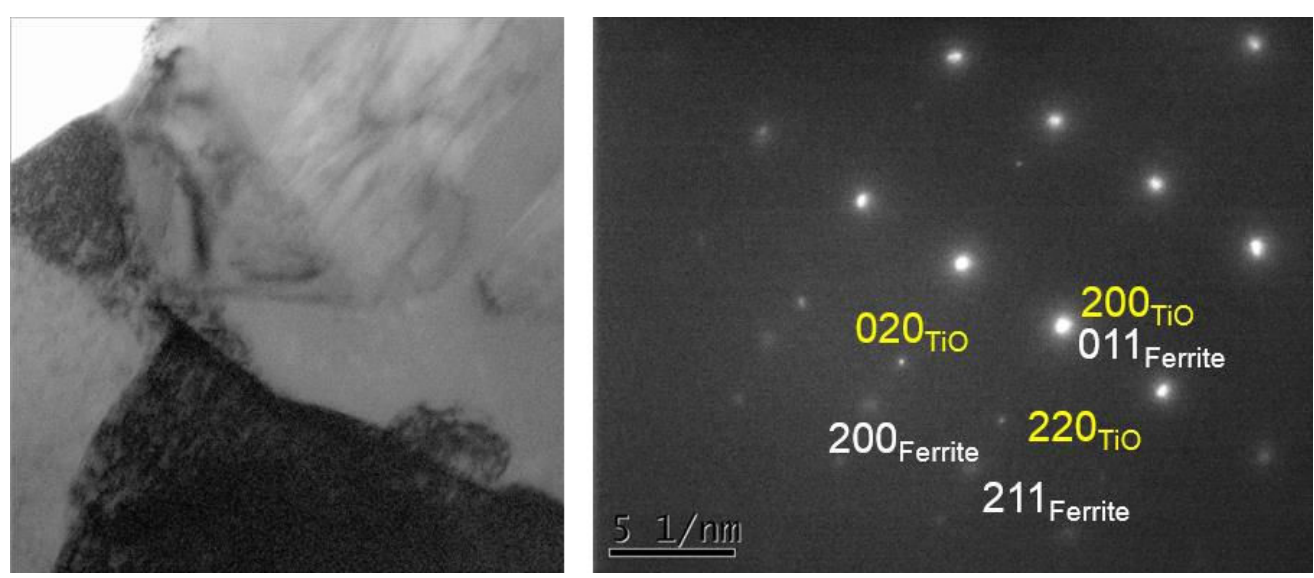

Fig. 5 The interface between the inclusion and ferit: (a) bright field image; (b) SADP obtained from the interface

SI. 5. Međupovršina uključka i ferita: (a) polje svetlih slika; (b) SADP zapažen sa međupovršine

As shown in the figures, surprisingly, the Ti element in the inclusions extracted from the high temperature areas (Fig. 9(d) and (e)) disperse in the inclusions; on the other hand, one extracted from the low temperature area (Fig. 9(f)) agglomerate into the phase inside the inclusion, and additionally form the surface Ti layers. The results indicate that the Tirich phase such as spinel structures and $\mathrm{TiO}$ layers form not at the high temperature such as molten steel temperature but at below the solid phase temperature such as austenite or ferrite temperature. Figure 10 shows the mass of inclusion phases in each temperature. As shown in the figure, in the welding process, a slag phase initially form at $1850^{\circ} \mathrm{C}$, and a Ti-spinel phase form at $1250^{\circ} \mathrm{C}$. Even though a $\mathrm{TiO}$ phase was contained in the calculation, a $\mathrm{TiO}$ phase did not form. The result indicate that only the slag phase form at high temperature such as molten steel temperature and the solid oxide phases such as spinel structure form below the austenite temperature.
Kao što je prikazano na slikama, začudo, $\mathrm{Ti}$ elemenat u uključcima ekstraktovanim iz visokotemperaturnih oblasti (sl.9(d) i (e)) raspoređen je u uključcima; a sa druge strane, onaj ekstraktovan iz niskotemperaturne oblasti (sl. 9(f)) se gomila u fazu unutar uključka i dodatno sa površine Ti slojeva. Rezultati indikuju da faza bogata Ti kao što su strukture spinela i slojevi TiO ne nastaju na visokim temperaturama poput temperature rastopa čelika već na nižim od tempratura transformacija u čvrstom stanju kao što su temperature austenite ili ferita. $\mathrm{Na}$ slici 10. pokazana je masa faza uključaka na svakoj temperaturi. Kao što je prikazano na slici, tokom procesa zavarivanja, faza šljake inicijalno se stvara na $1850^{\circ} \mathrm{C}$, a faza Ti-spinel na $1250^{\circ} \mathrm{C}$. lako je faza TiO uzeta u razmatranje pri proračunu, faza TiO se ne stvara. Rezultat indikuje da se samo faza šljake stvara na visokoj temperaturi poput temperature rastopljenog čelika i faze čvrstih oksida kao što je struktura spinela koja nastaje ispod temperature austenita.
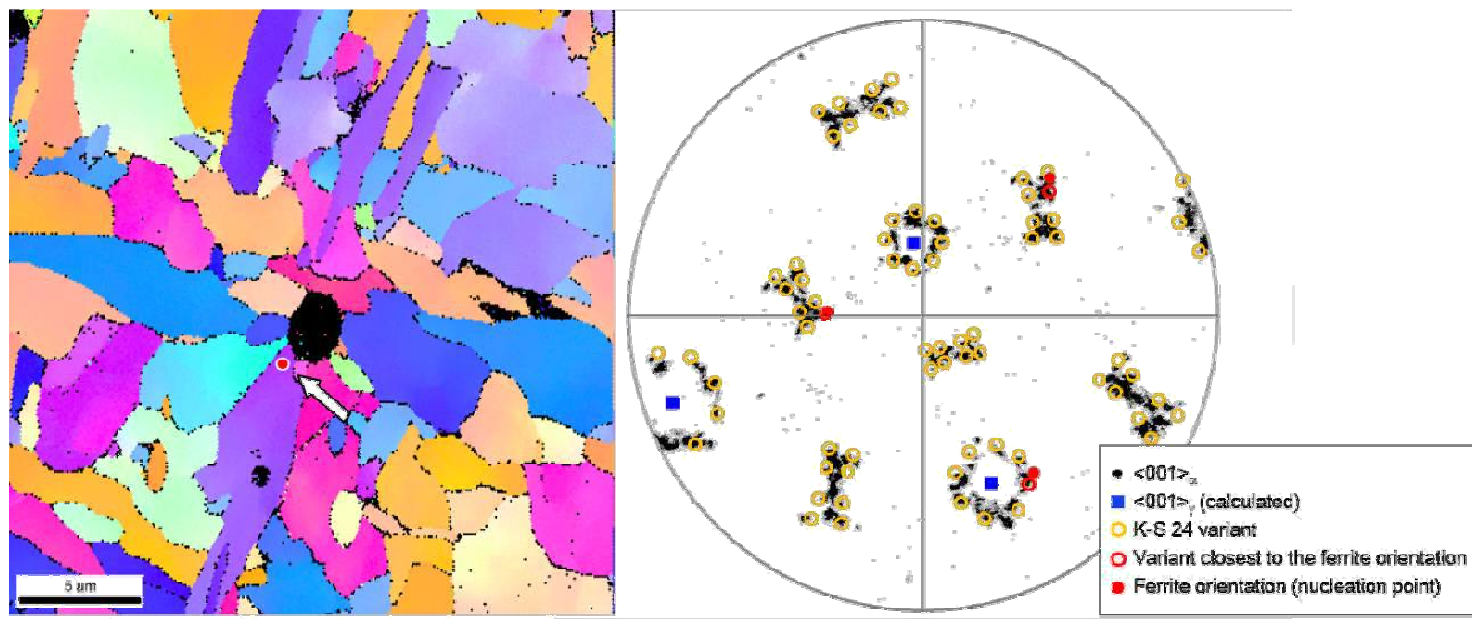

Fig. 6 The EBSD analysis: (a) the IPF map of ferit; (b) the <001> pole figure SI.6. EBSD analiza (a) IPF mapa ferita; (b) slika <001> pola 


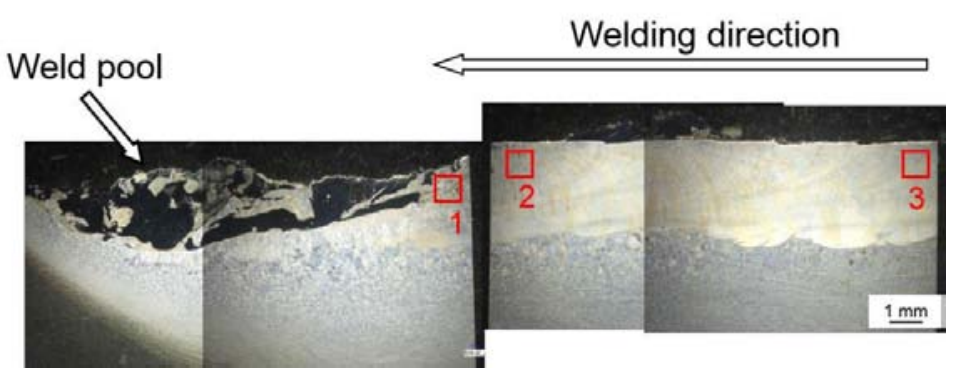

Fig. 7 The cross section image of quenching weld metal Sl.7. Slika poprečnog preseka metala šava

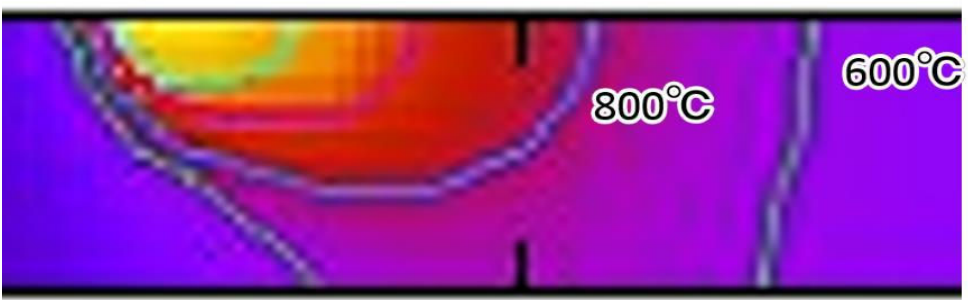

Fig. 8 The simulated thermal contribution SI. 8. Simulirana raspodela toplote

\section{Discussion}

The results of the liquid-tin quenching technique and the thermodynamic calculation indicated that $\mathrm{Ti}$ phase such as a spinel structure form at austenite temperature. Thus, the TiO would also form below the austenite temperature. Concerning the TiO formation temperature, two cases are considered; the first case is at austenite temperature range, and the second case is at ferrite temperature range. In case $\mathrm{TiO}$ form at austenite temperature, $\mathrm{TiO}$ would have a specific orientation relationship with austenite. However, the specific orientation relationship is not observed between the $\mathrm{TiO}$ and prior austenite.

\section{Diskusija}

Rezultati tehnike kaljenja tečnim kalajem i termodinamički proračun indikuju $\mathrm{Ti}$ fazu kao strukturu spinela nastalu na temperature austenita. Šta više, TiO takođe može da nastane ispod austenitne temperature. Uzimajući u obzir temperature nastajanja $\mathrm{TiO}$, razmatraju se dva slučaja; prvi slučaj u opsegu austenitne temperature I drugi slučaj, u opsegu feritne temperature. U slučaju stvaranja TiO na austenitnoj temperaturi, TiO može da ima specifičnu orijentaciju odnosa sa austenitom. Međutim, specifična orijentacija nije zapažena između TiO i primarnog austenita.
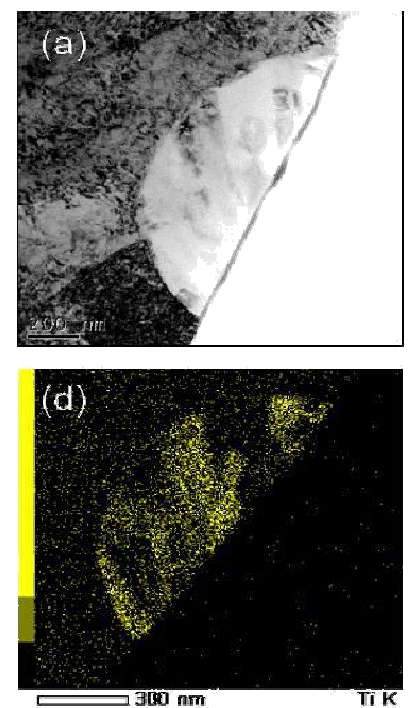
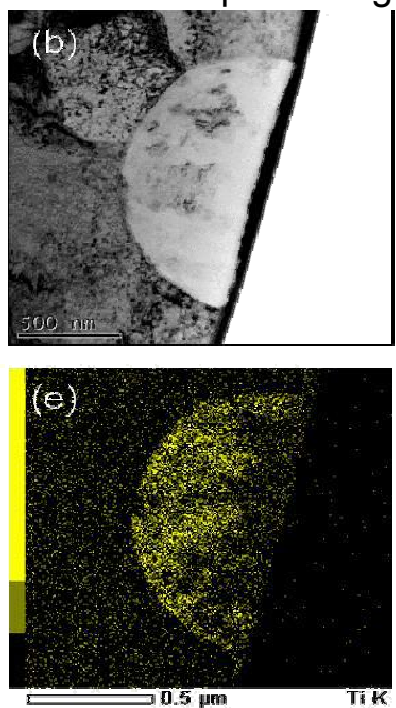
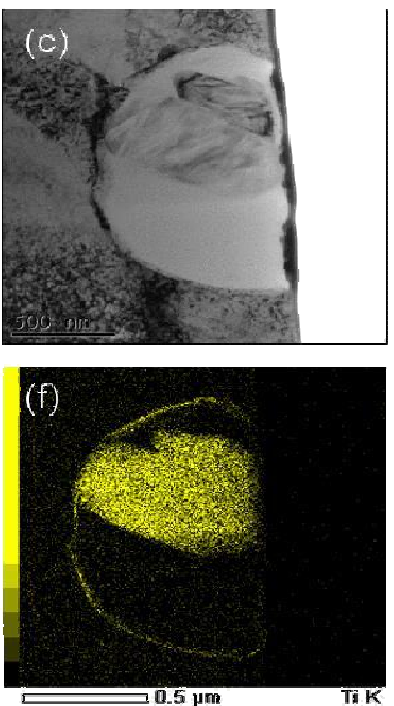

Fig. 9 The inclusions obtained from the numbered areas: (a) (c) TEM micrograph extracted from numbered areas; (d) (f) Ti distributions

SI.9. Uključci zapaženi u numerisanim oblastima: (a) (c) TEM mikrografi ekstraktovani iz numerisanih oblasti; (d) (f) raspodele $\mathrm{Ti}$ 


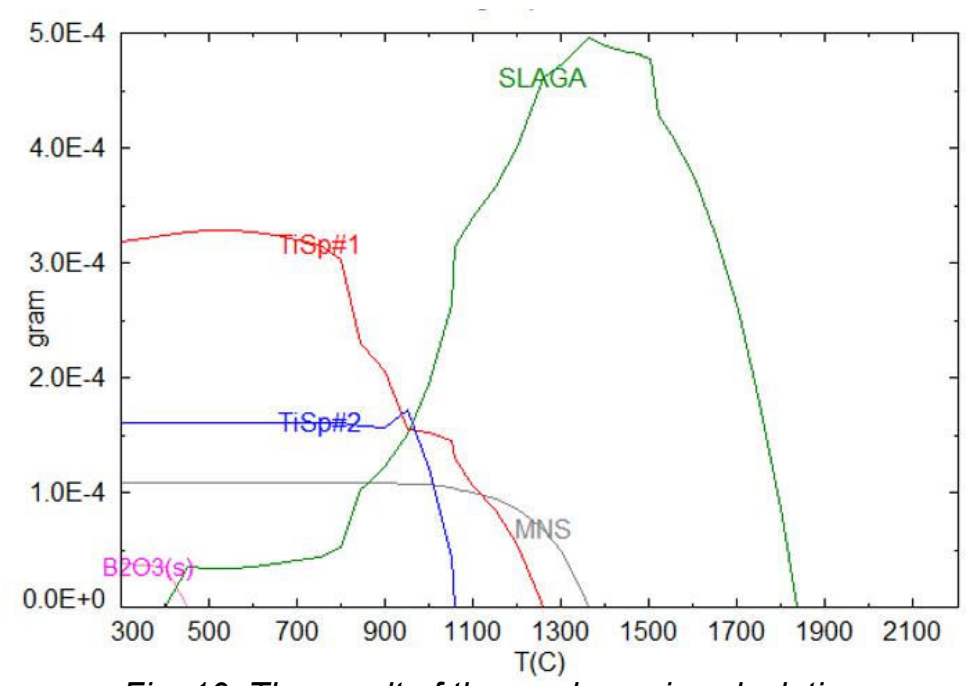

Fig. 10 The result of thermodynamic calculation

SI.10. Rezultat termodinamičkog proračuna

Thus, it is reasonable to consider that the TiO layer form at ferrite temperature range; in other words, the $\mathrm{TiO}$ layer form after the acicular ferrite formation. TiO is known to be as unstable phase in thermodynamically ${ }^{19)}$. As for the reason of $\mathrm{TiO}$ formation, it can be assumed that the TiO layer formed due to the low misfit with acicular ferrite. Therefore, the acicular ferrite nucleation and $\mathrm{TiO}$ formation are assumed as following. At first, acicular ferrite nucleate with the KurdjumovSachs orientation relationship. And then, TiO layers form with the Baker-Nutting orientation relationship with acicular ferrite. When TiO form after acicular ferrite nucleation, the mechanism of acicular ferrite nucleation would not be the low misfit theory.
Prema tome, opravdano je smatrati da se sloj TiO stvara u opsegu feritne temperature; drugim rečima, sloj TiO nastaje posle stvaranja acikularnog ferita. $U$ termodinamičkom smislu ${ }^{19)}$ TiO je poznat kao nestabilna faza. Kao razlog za stvaranje TiO, može se pretpostaviti da se sloj TiO stvara zbog niskog neslaganja sa acikularnim feritom. Dakle, nukleacija acikularnog ferita i stvaranje TiO su prepostavljeni kako sledi. Kao prvo, acikularni ferit se ujezgrava sa Kurdjumov-Sachs orijentaciom odnosa. A onda se slojevi TiO stvaraju sa BakerNutting orijentacijom odnosa sa acikularnim feritom. Kada se TiO formira posle nukleacije acikularnog ferita, mehanizam nukleacije acikularnog ferita ne može biti teorija niskog neslaganja.

\section{(a) Across TiO layer}
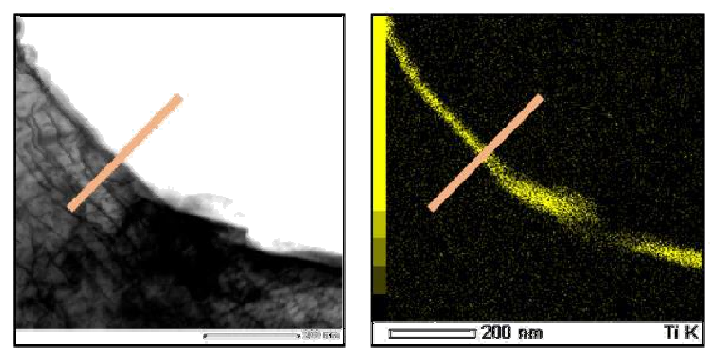

(b) Across MnS
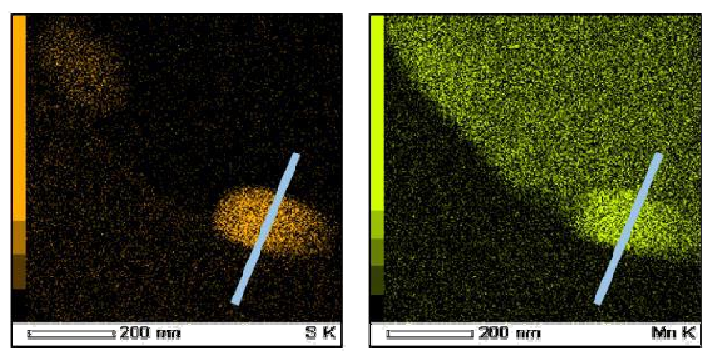
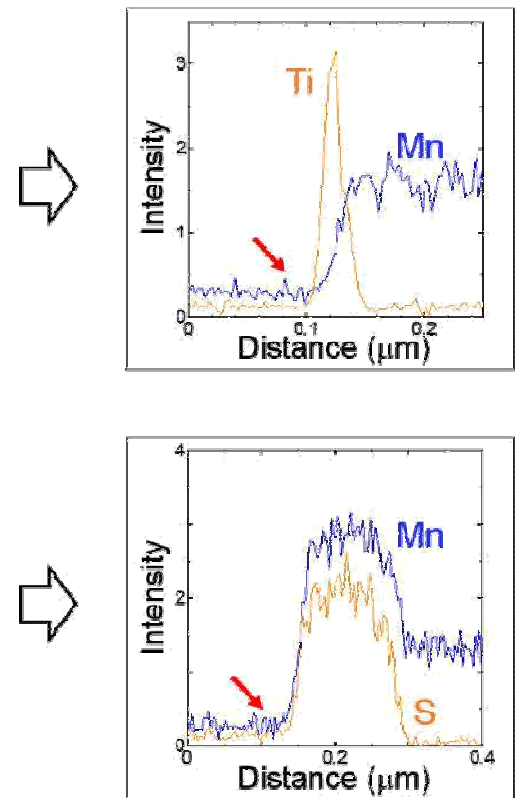

Fig. 11 The measurement of Mn: (a) across TiO layer; (b) across MnS SI. 11 Merenje Mn: (a) preko sloja TiO; (b) preko MnS 
The low misfit between inclusion phase and ferrite has been believed as the important mechanism stimulating the acicular ferrite nucleation. The interfacial energy become the lowest when the coherent interface are formed. In this case, however, only the ferrite/inclusion interface has been considered. At the time of acicular ferrite nucleation, the two types of interface are formed. One is a ferrite/inclusion interface, and the other is a ferrite/austenite interface. Thus, the ferrite/austenite interfacial energy must be considered as well as the ferrite/inclusion interfacial energy. The acicular ferrite nucleation would not be stimulated when only one interface are matched. For example, it is known that TiN particles do not have much potential for acicular ferrite nucleation, though TiN have the low misfit with ferrite.

As for the reason, TiN particle have cube-cube orientation relationship with austenite. Acicular ferrite nucleating from $\mathrm{TiN}$ with the BakerNutting orientation relationship have the Bain orientation relationship with austenite. There is a deviation between the Bain orientation relationship and the KurdjumovSachs orientation relationship; thus, the ferrite/austenite interfacial energy increase in case acicular ferrite nucleates from TiN.

In case the low misfit theory is not the main mechanism of acicular ferrite nucleation, the $\mathrm{Mn}$ depleted zone is considered as another important mechanism. The mechanism is the theory that the driving force for ferrite nucleation increase by the formation of $\mathrm{Mn}$ depleted zone around inclusions. $\mathrm{Mn}$ element around inclusions are considered to be absorb into $\mathrm{Ti}_{2} \mathrm{O}_{\mathrm{s}}$ or MnS. In the present study, the measurement of Mn depleted zone was carried out.

The results are shown in Fig. 11. As shown in the figure, however, the $\mathrm{Mn}$ depleted zone is not observed. Thus, the mechanism is also not considered as the main mechanism of acicular ferrite nucleation. From above results, it can be considered that the low misfit theory and the theory of Mn depleted zone are not the main mechanisms. Another mechanism is considered to act as the acicular ferrite nucleation; therefore, further consideration will be needed about acicular ferrite nucleation mechanisms.
Nisko neslaganje između faza uključaka i ferita je smatrano značajnim mehanizmom stimulisanja nukleacije acikularnog ferita. Energija na međupovršini postaje najmanja kada se stvara koherentna međupovršina. U tom slučaju, međutim, razmatra se samo međupovršina ferit/uključak. U vreme nukleacije acikularnog ferita, formirana su dva tipa međupovršina. Jedna je međupovršina ferit/uključak, a druga je međupovršina ferit/austenit. Tako se moraju uzeti u obzir i energija međupovršine ferit/austenit kao i energija međupovršine ferit/uključak. Nukleacija acikularnog ferita ne može biti stimulisana kada se samo jedna međupovršina podudara. Na primer, poznato je da čestice TiN nemaju veliki potencijal za nukleaciju acikularnog ferita, iako TiN ima nisko ne slaganje sa feritom.

Što se tiče razloga, čestica $\mathrm{TiN}$ ima orijentaciju odnosa kocka-kocka sa austenitom. Acikularni ferit koji se ujezgrava iz TiN sa Baker-Nutting orijentacijom odnosa ima Bain orijentaciju odnosa sa austenitom. Postoji odstupanje između Bain i Kurdjumov-Sachs orijentacije odnosa; zato energija međupovršine ferit/austenit raste u slučaju acikularnog ferita koji nastaje iz TiN.

U slučaju da teorija niskog neslaganja nije glavni mehanizam nukleacije acikularnog ferita, zone osiromašene $M n$ se smatraju drugim važnim mehanizmom. Mehanizam je teorija da sila pokretanja nukleacije ferita raste sa stvaranjem zona osiromašenih Mn oko uključaka. Element $\mathrm{Mn}$ oko uključaka se smatra absorbovanim u $\mathrm{Ti}_{2} \mathrm{O}_{\mathrm{s}}$ ili MnS. U ovoj studiji, sprovedeno je merenje zone osiromašene $\mathrm{Mn}$.

Rezultati su prikazani na sl.11. Kao što je prikazano na slici, međutim, nisu zapažene zone osiromašene $\mathrm{Mn}$. Zato ovaj mehanizam takođe nije razmatran kao glavni mehanizam nukleacije acikularnog ferita. Iz ovih rezultata se može smatrati da teorija niskog neslaganja i teorija zone osiromašene na $\mathrm{Mn}$ nisu glavni mehanizmi. Razmatraju se drugi mehanizmi koji deluju na nukleaciju acikularnog ferita, Smatra se da drugi mehanizam deluje na nukleaciju acikularnog ferita; zbog toga, naredna razmatranja treba da obuhvate mehanizme nukleacije acikularnog ferita. 


\section{Conclusions}

Acicular ferrite was investigated from the viewpoint of crystallographic feature among acicular ferrite, prior austenite, and inclusions. The conclusions obtained in this study are described as follows:

1. Inclusions consisted of the multi-phases. The amorphous phase, the spinel structures, a-MnS, and $\mathrm{TiO}$ layer were observed.

2. The Baker-Nutting orientation relationship was observed between acicular ferrite and a TiO layer forming at the inclusion surface.

3. The Kurdjumov-Sachs orientation relationship was observed between acicular ferrite and prior austenite.

4. From the results of liquid-tin quenching technique and thermodynamic calculation, the $\mathrm{TiO}$ layer is considered to form after acicular ferrite nucleation. The TiO layer is considered to form due to the low misfit with acicular ferrite.

5. The Mn depleted zone around inclusion were also not observed.

6. It can be considered that the low misfit theory and the theory of $\mathrm{Mn}$ depleted zone are not the main mechanisms. Another mechanism is considered to act as the acicular ferrite nucleation

\section{Reference}

1) R. A. Farrar and P. L. Harrison: 'Acicular ferit in carbon-manganese weld metals: an overview', J. Mat. Sci., 22(1987), 3812-3820.

2) T. Koseki: 'Microstructure Development and Control in Steel Welds'. Tetsu-to-Hagane, 90(2004), 61-72.

3) F. J. Barbaro, P. Krauklis, and K. E. Easterling: 'Formation of acicular ferit at oxide particles in steels', Mat. Sci. Tech., 3(1987), 1051-1061.

4) R. A. Ricks, P. R. Howell, and G. S. Barritte: 'The nature of acicular ferit in HSLA steel weld metals', $J$. Mat. Sci., 17(1982), 732-740.

5) M. Díaz-Fuentes A. Iza-Mendia, and I. Gutiérrez: 'Analysis of Different Acicular Ferit Microstructures in Low-Carbon Steels by Electron Backscattered Diffraction. Study of Their Toughness Behavior', Metallurgical Mat. Tran. A, 34(2003), 2505-2516.

\section{Zaključci}

Istraživan je acikularni ferit sa tačke gledišta kristalografskih funkcija među acikularnim feritom, primarnim austenitom i uključcima. Ustanovljeni zaključci u ovoj studiji se mogu opisati na sledeći način:

1. Uključci se sastoje od vise faza. Zapažene su amorfne faze, strukture spinela, a-MnS, i sloja TiO.

2. Orijentacija odnosa Baker-Nutting zapažena je između acikularnog ferita i sloja TiO koji se stvara na površini uključka.

3. Orijentacija odnosa Kurdjumov-Sachs zapažena je između acikularnog ferita i primarnog austenita.

4. Na osnovu rezultata tehnike kaljenja tečnim kalajem i termodinamičkog proračuna, smatra se da se sloj TiO stvara posle nukleacije acikularnog ferita. Smatra se da sloj TiO nastaje zbog niskog neslaganja sa acikularnim feritom.

5. Zona osiromašena na Mn oko uključka nije zapažena.

6. Može se smatrati da teorija malog neslaganja i teorija zone osiromašene na $\mathrm{Mn}$ nisu glavni mehanizmi. Smatra se da drugi mehaizam deluje na nukleaciju acikularnog ferita.

6) H. Terasaki and Y. Komizo: 'In situ observation of morphological development for acicular ferit in weld metal', Sci. Tech. Weld. Join., 11(2006), 561-566.

7) S. S. Babu: 'The mechanism of acicular ferit in weld deposits', Cur. Opinion in Solid StateMat. Sci.,8(2004), 267-278.

8) Y. Kitani, Y. Ohkita, R. Ikeda, M. Ono, and K. Ikeuchi: 'Improvement in Laser Weld Metal Toughness of Low C Steel by Refining Microstructure', Q. J. Japan Weld. Soc., 27(2009), 55-60.

9) Y. Kitani, R. Ikeda, M. Ono, and K. Ikeuchi: 'Improvement in Weld Metal Toughness in High Heat Input Electroslag Welding of Low Carbon Steel', Q. J. Japan Weld. Soc., 27(2009), 240-246. 
10) H. M. Flower and T. C. Lindley: 'Electron backscattering diffraction study of acicular ferit, bainite, and martensite steel microstructures', Mat. Sci. Tech., 16(2000), 26-40.

11) J. M. Gregg and H. K. D. H. Bhadeshia: 'SOLIDSTATE NUCLEATION OF ACICULAR FERIT ON MINERALS ADDED TO MOLTEN STEEL', Acta mater.,45(1997), 739-748.

12) T. K. Lee, H. J. Kim, B. Y. Kang, and S. K. Hwang: 'Effect of inclusion size on the nucleation of acicular ferit in welds', ISIJ int., 40(2000), 1260-1268.

13) J. M. Dowling, J. M. Corbett, and H. W. Kerr: 'Inclusion Phase and the Nucleation of Acicular Ferit in Submerged Arc Welds in High Strength Low Alloy Steels', Metallurgical Tans. A,17(1986), 16111623.

14) A. R. Mills, G. Thewlis, and J. A. Whiteman: 'Nature of inclusions in steel weld metals and their influence on formation of acicular ferit', Mat. Sci. Tech., 3(1987), 1051-1061.

15) Z. Zhang and R. A. Farrar: 'Role of non-metallic inclusions in formation of acicular ferit in low alloy weld metals', Mat. Sci. Tech., 12(1996), 237-260.

16) T. Yamada, H. Terasaki, and $Y$. Komizo: 'Relation between Inclusion Surface and Acicular Ferit in Low Carbon Low Alloy Steel Weld', ISIJ Int., 49(2009), 1059-1062.
17) J. -S. Byun, J. -H. Shim, Y. W. Cho, and D. N. Lee: 'Non-metallic inclusion and intragranular nucleation of ferit in Ti-killed CMn steel', Acta Mater., 51(2003), 1593-1606.

18) G. Shigesato, M. Sugiyama, S. Aihara, R. Uemori, and Y. Tomita: 'Effect of Mn Depletion on Intragranular Ferit Transformation in Heat Affected Zone of Welding in Low Alloy Steel', Tetsu-to-Hagane, 87(2001), 23-30.

19) K. Kasai, C. Lee, S. Nambu, J. Inoue, and T. Koseki: 'Transformation Behavior of Ferit at Steel/B1 compounds Interface', Tetsu-to-Hagane, 96(2010), 23-28.

20) M. Yonemura, T. Osuki, H. Terasaki, Y. Komiso, M. Sato, and A. Kitano: 'In-situ observation for Weld Solidification in Stainless Steels Using TimeResolved X-ray Diffraction', 47(2006), 310-316.

21) G. Miyamoto, N. Iwata, N. Takayama, and T. Furuhara: 'Mapping the parent austenite orientation reconstructed from the orientation of martensite by EBSD and its application to ausformed martensite', Acta Mater., 58(2010), 6393-6403. 